\title{
Kjønn som "forsømt" variabel innen perinatal epidemiologisk årsaksforskning
}

\author{
Leiv S. Bakketeig ${ }^{1}$, Torstein Vik ${ }^{2}$ og Rolv Skjærven ${ }^{3}$ \\ 1) Institut for Sundhedstjenesteforskning (Institute of Public Health), Syddansk Universitet, Odense \\ 2) Institutt for samfunnsmedisinske fag, NTNU, Trondheim \\ 3) Seksjon for medisinsk statistikk, Universitetet i Bergen
}

Korrespondanse: Leiv S. Bakketeig, Institut for Sundhedstjenesteforskning, Syddansk Universitet, Odense, Winsløwparken 17.1, 5000 Odense C, Danmark

Telefon: +456550 3069 telefax: +45 65906938 e-post: 1-bakketeig@win-chs.sdu.dk

\section{INNLEDNING}

Innen deskriptiv epidemiologi er universelle variable som alder og kjønn viet stor oppmerksomhet. Det sies spøkefullt at en definisjon på en epidemiolog er: "an inividual broken down by age and sex".

Perinatal epidemiologi fokuserer på forholdet mellom eksposisjoner i svangerskapet, under og kort etter fødsel og senere sykdom og utviklingsforstyrrelser. I de senere år er det blitt vanlig å relatere perinatale eksposisjoner til sykdomstilstander gjennom oppvekst, ungdomstid og inn i voksen alder. Ved beskrivelse av sykdomstilstander innen perinatal epidemiologi vies kjønn stor oppmerksomhet.

Og sykdommer opptrer til dels med ulik hyppighet blant gutter og jenter. Som vist i Tabell 1 er det til dels betydelige kjønnsforskjeller i risikoen for å få enkelte sykdommer. En forenklet gruppering av sykdommene i forhold til årsaker, antyder at jenter har økt risiko for å utvikle en del autoimmune sykdommer, som ulcerøs kolitt, morbus Crohn, coeliaki, noen former for revmatoid artritt, og autoimmune thyreoideasykdommer
(1-3). For fullstendighetens skyld skal det imidlertid presiseres at andre autoimmune sykdommer synes å forekomme like hyppig blant gutter som blant jenter (f.eks. diabetes mellitus og den systemiske formen av revmatoid artritt), eller også hyppigere blant gutter (f.eks. Bechterews sykdom) $(1,3)$. Gutter synes først og fremst å ha økt risiko for sykdommer hvor man mener at årsakene kan være skader før eller under fødselen, som f.eks. cerebral parese og hyperaktivitet og konsentrasjonvansker (ADHD) (4-7).

Kjønn er derfor en sentral variabel når sykdommenes forekomst beskrives. Men når potensielle årsaksfaktorer beskrives, vies ikke variabelen kjønn den samme oppmerksomhet. Det kunne jo tenkes at risikofaktorer for uheldige svangerskapsutfall virker forskjellig avhengig av fosterets kjønn. Og hvis dette viste sig å være tilfelle, kunne forholdet lede til bedre forståelse av årsaksforholdene og sykdomsmekanismene.

I denne artikkelen vil vi fokusere på noen eksempler hvor kjønn synes å spille en rolle i samspillet mellom en årsakfaktor og et uønsket utfall.

Tabell 1. Forskjeller i risiko (odds ratio) for sykdom blant gutter og jenter.

\begin{tabular}{lcc}
\hline & OR (jenter versus gutter) & Kilder \\
\hline Autoimmune sykdommer & & \\
Ulcerøs kolitt & $1,2-1,5$ & $(1)$ \\
Crohns sykdom & $1,3-1,5$ & $(1)$ \\
Coeliaki & 1,6 & $(2)$ \\
Reumatoid artritt: pauciartikulær & 2,5 & $(1)$ \\
$\quad$ polyartikulær & 1,5 & $(1)$ \\
Autoimmun hypotyreose & $4,0-7,0$ & $(3)$ \\
Graves sykdom (hypertyreose) & 5,0 & $(3)$ \\
Mulig intrauterine/ perinatale årsaker & & \\
Intellektuell funksjonshemning & 0,83 & $(4)$ \\
Cerebral parese & 0,5 & $(5)$ \\
& 0,85 & $(6)$ \\
ADHD* & 0,4 & $(7)$ \\
\hline
\end{tabular}

* Attention deficit and hyperactivity disorder 


\section{FORSKJELLIG EFFEKT AV RØYKING I SVANGERSKAPET PÅ GUTTERS OG JENTERS PRE- OG POSTNATALE VEKST}

Vi har tidligere publisert en undersøkelse av effekten av den gravide mors røyking på fosterets pre- og postnatale vekst (8). Vi fant her at eksponering for mors røyking in utero først og fremst påvirket midabdominal diameter hos jentefostrene. Disse resultatene kan tyde på at effekten av røyking på veksten til jentefostere først og fremst påvirker veksten av subkutant fett og lever (glykogen), og at veksthemningen pga. sigarettrøyking dermed er mer "asymmetrisk" hos jentefostere enn hos guttefostere. Men vi fant likevel ingen slik effekt bedømt ved ponderal index ved fødselen.

Ved ett års alder var guttebarn av røykende mødre kortere enn guttebarn av ikke-røykende mødre, mens jentebarn av røykende mødre hadde lavere hodeomkrets enn jentebarn av ikke-røykende mødre. Ved fem års alder var disse kjønnsforskjellene forsvunnet, og det var ingen signifikant forskjell i hodeomkrets eller lengdevekst mellom barn av røykende og ikke-røykende mødre, hverken for gutter eller jenter. Derimot fant vi ved fem års alder, at jentebarn av røykere var fetere, bedømt både ved ponderal index og subscapular skinfold thickness, enn jentebarn av ikke røykere. For gutter var en tilsvarende trend ikke statistisk signifikant. I studien spekulerte vi på om det faktum at barn av røykere var fetere enn barn av ikke røykere, skyldtes et usunnere kosthold hos barn av røykende mødre. At denne effekten bare skulle slå ut hos jenter, kan i så fall skyldes at jentene er mer påvirkelig av sine mødre når det gjelder kostvaner enn gutter, allerede i de fem første leveår. Dette passer med nylig publiserte studier av overvekt hos barn, som tyder på at varige kostvaner kan være etablert allerede så tidlig som ved fem års alder (9).

Disse eksemplene viser at sigarettrøyking hos mødrene interagerer med barnas kjønn og gjør således ulike utslag for barnas vekst og utvikling.

\section{HAR ULTRALYDUNDERSØKELSER I SVANGERSKAPET SPESIELLE EFFEKTER PÅ FOSTRENE AVHENGIG AV KJØNN?}

Noen klare skadeeffekter av ultralydeksponering i svangerskapet er hittil ikke blitt oppdaget.

Barna fra tre randomiserte forsøk er blitt fulgt opp ved skolealderens start, for å avdekke evt. utviklingsforstyrrelse, herunder hendthet (venstrehendt eller høyrehendt). Barnas hendthet ble målt ved hjelp av et spørreskjema til foreldrene. I alt 4.715 barn i alderen 8-9 år inngikk i en metaanalyse (10). Av metaanalysen fremgikk det at det ikke var noen statistisk signifikante forskjeller av prevalensen av "ikke høyrehendte" mellom barn av ultralydscreenede mødre og kontrollbarn, $\mathrm{OR}=1,13(0,97-1,32)$. Det var imidlertid en signifikant forskjell blant guttebarn, OR $=1,26(1,03-1,54)$, og ikke blant jentebarna. Hvis man foretok en eksplo- rativ analyse etter hvorvidt mødre hadde virkelig blitt ultralydundersøkt (ikke bare "intention to treat") ble sammenhengen sterkere OR $=1,19(1,02-1,38)$ for begge kjønn, og OR økte til $1,34(1,10-1,65)$ for guttebarn.

Vi har her et eksempel på at en ikke tiltenkt effekt av en eksposisjon slår ulikt ut på barna avhengig av kjønn. I videre analyser av slike sammenhenger er det viktig å ta høyde for kjønnsforskjeller. Den mulige interaksjon mellom kjønn og effekten av eksposisjonen kan innebære nøkkelen til forståelse av årsaksmekanismene.

\section{INTERAGERER MØDRENES DIABETES MED BARNETS KJØNN OG PÅVIRKES PERINATAL SYKELIGHET OG DØDELIGHET?}

Det har vært vist at guttebarn har høyere perinatal sykelighet enn jentebarn hvis mødrene er diabetikere. Bracero og medarbeidere (11) viste at denne oversykelighet blant guttebarna skyldtes en høyere insidens av hypoglykemi (relativ risiko $=3,9(1,2-12,5)$ ), noe som førte til at de nyfødte barna oftere måtte tilbringe 2 eller flere dager $\mathrm{i}$ "neonatal intensive care" (relativ risiko $=1,8(1,1-2,9))$. Guttekjønn var en av tre uavhengige prediktorer for "dårlig utfall". Bracero og medarbeidere relaterte imidlertid ikke denne oversykelighet blant guttebarna til den vanlige oversykelighet blant guttebarn omkring fødsel.

Data fra Medisinsk fødselsregister viser at overdødeligheten blant guttebarn av diabetiske mødre omkring fødsel ikke var større enn forventet basert på den alminnelige overdødelighet blant guttefostere/barn.

Tabell 2 viser lav Apgar score $(<7)$ etter 1 og 5 minutter blant guttebarn og jentebarn etter hvorvidt mødrene hadde diabetes. Tabellen viser at lav Apgar score som ventet er hyppigere blant guttebarn enn blant jentebarn. Således forekom lav Apgar score $(<7)$ etter 1 minutt for 10,4\% av guttebarn født av diabetiske mødre, mot for $9,1 \%$ for tilsvarende jentebarn. Dette gir en relativ hyppighet på 1,14 for guttebarn (14\% hyppigere). Tilsvarende relativ hyppighet blant guttebarn av ikke-diabetiske mødre var 1,26 (26\% hyppigere). Eller, som vist i Tabell 2, den relative risiko for lav Apgar score var 2,2 blant guttebarna hvis mødre hadde diabetes, mens den tilsvarende relative hyppighet var 2,4 blant jentene.

Lav Apgar score $(<7)$ etter 5 minutter viser imidlertid litt andre relasjoner mellom gutte- og jentebarn. Lav Apgar score fantes hos 2,7\% av guttebarna født av diabetiske mødre, mens bare hos $2,1 \%$ av jentebarna. Dette gir en noe høyere relativ hyppighet på 1,29 for guttebarna. Blant barn av ikke-diabetiske mødre var den relative hyppighet 1,18 for gutter sammenliknet med jenter. Eller, som vist i tabell 2 , den relative risiko for lav Apgar score etter 5 minutter var 2,1 for gutter av diabetiske mødre mot 1,9 blant jentene.

Overvåking av diabetiske mødre har bedret sig betydelig over den 32-års perioden som er fremstilt i 
Tabell 2. Lav Apgar score $(<7)$ for gutter og jenter etter hvorvidt mødrene var diabetikere eller ikke. Basert på 1,82 millioner levendefødte (enkeltfødte) barn i Norge 1967-98 og separarat for 586 tusen barn født i den siste 10-års perioden (1989-98).

\begin{tabular}{l|cc|cc|cc|cc}
\hline \multirow{2}{*}{} & \multicolumn{4}{|c|}{ Lav Apgar score (<7) etter 1 minutt } & \multicolumn{3}{c}{ Lav Apgar score (<7) etter 5 minutter } \\
\cline { 2 - 10 } & \multicolumn{2}{|c|}{ gutter } & \multicolumn{2}{c|}{ jenter } & \multicolumn{2}{c}{ gutter } & \multicolumn{2}{c}{ jenter } \\
\cline { 2 - 10 } & $\%$ & OR & $\%$ & OR & $\%$ & OR & $\%$ & OR \\
\hline $\mathbf{1 9 6 7 - 9 6}$ & & & & & & & & \\
$\quad$ Diabetiske mødre & 10,4 & 2,2 & 9,1 & 2,4 & 2,7 & 2,1 & 2,1 & 1,9 \\
$\quad$ Ikke-diabetiske mødre & 4,8 & 1,0 & 3,8 & 1,0 & 1,3 & 1,0 & 1,1 & 1,0 \\
$\mathbf{1 9 8 9 - 9 8}$ & & & & & & & & \\
$\quad$ Diabetiske mødre & 10,4 & 2,2 & 8,3 & 2,2 & 2,5 & 1,9 & 2,0 & 1,8 \\
$\quad$ Ikke-diabetiske mødre & 4,9 & 1,0 & 3,9 & 1,0 & 1,3 & 1,0 & 1,1 & 1,0 \\
\hline
\end{tabular}

Tabell 2. Imidlertid viser det seg (Tabell 2, nedre del) at det relative mønsteret er stort sett tilsvarende når vi sammenlikner barn av diabetiske og ikke-diabetiske mødre, separat for de to kjønn, for den siste 10-års perioden (1989-98). Data vist her gjelder Apgar score. Vi har imidlertid studert perinatal og neonatal dødelighet som utfallsvariable og funnet som ventet tilsvarende mønstre ettersom lav Apgar score er nært assosiert med dødelighet.

Dette er et eksempel på at en tilsynelatende interaksjon mellom kjønn, en risikovariabel og utfallet av svangerskapet ikke synes å være til stede ved analyse i et større datasett.

\section{KJØNN INTERAGERER MED SVANGERSKAPSVARIGHET}

I perioden 1967-98 ble det i Norge født 86.158 for tidlig fødte barn. Av disse var 48.660 guttefostere/barn (56,5\%, Tabell 3). Til sammenligning var 51,4\% av samtlige fødte gutter. Som vist i tabellen var andelen gutter blant fødte i ukene 28-36 omtrent den samme som for alle for tidlig fødte $(<37$ uker). I svangerskapsperioden 22-27 uker var gutteandelen litt lavere $(54,1 \%$ og 55,0\%), mens den i motsetning til dette var klart høyere for de som var ekstremt for tidlig fødte, $75,8 \%$ og $60,9 \%$ for henholdsvis fødte etter $16-18$ og 19-21 uker.

\section{KONKLUSJON}

Vi mener at kjønn er en kritisk variabel som må tas med i analyse av risikovariabler og sykdomsutfall, også som mulig interagerende variabel med eksposisjon (risiko) og utfall.

Tabell 3. Andelen gutter blant for tidlig fødte (før 37 uker) etter fosteralder samt deres perinatale dødelighet sammenliknet med alle fødte (begge kjønn), Norge, 1967-98.

\begin{tabular}{lcrr}
\hline Fosteralder & Totalt antall & \multicolumn{2}{c}{ Herav gutter } \\
\cline { 3 - 4 } (uker) & fødte & antall & $\%$ \\
\hline $16-18$ & 654 & 496 & 75,8 \\
$19-21$ & 1929 & 1174 & 60,9 \\
$22-24$ & 2611 & 1413 & 54,1 \\
$25-27$ & 3736 & 2054 & 55,0 \\
$28-30$ & 5952 & 3369 & 56,6 \\
$31-33$ & 13445 & 7669 & 57,0 \\
$34-36$ & 57831 & 32485 & 56,2 \\
\hline Totalt (for tidlig fødte) & 86158 & 48660 & 56,5 \\
\hline
\end{tabular}

\section{LITTERATUR}

1. Krasilnikoff PA, Holmberg L, Lie SO, Schiøtz PO, Visakorpi JK. Nordisk Larebog i Pcediatri. Munksgaard, København, 1993.

2. Bode $\mathrm{SH}$, Gudmand-Hoyer E. Incidence and prevalence of symptomatic celiac disease among adults in Denmark. Ugeskr Laeger 1998; 160: 2100-4.

3. Behrman RE, Kliegman RM. Nelson Textbook of Pediatrics. 14th edition. Saunders, Philadelphia, 1992.

4. Gissler M, Järvelin MR, Louhiala P, Hemminki E. Boys have more health problems than girls: follow-up of the 1987 Finnish birth cohort. Acta Paediatr 1999; 88: 310-4.

5. Herder GA. Cerebral parese hos barn i Nordland 1977-91. Forekomst, årsaksforhold, handicap. Tidsskr Norsk Lageforen 1998; 118: 706-9.

6. Bottos M, Granato T, Allibrio G, Gioachin C, Puato ML. Prevalence of cerebral palsy in north-east Italy from 1965 to 1989. Dev Med Child Neurol 1999; 41: 26-39. 
7. McMurray MB, Barkley RA. The hyperactive child. In: David RB (ed). Child and Adolescent Neurology. Mosby, St. Louis, 1998.

8. Vik T, Jacobsen G, Vatten L, Bakketeig LS. Pre- and post-natal growth in children of women who smoked in pregnancy. Early Human Dev 1996; 45: 245-55.

9. Tyrell VJ, Gillies GF, Cutfield WS, Hofman PL, Richards GE. How much fat is there in the body mass index? Pediatr Res 1999; 45: 133A.

10. Salvesen KA, Eik-Nes SH. Ultrasound during pregnancy and subsequent childhood non-right handedness - a metaanalysis. Ultrasound Obstet Gynecol 1999; 13: 1-6.

11. Bracero LA, Cassidy S, Byrne DW. Effect of gender on perinatal outcome in pregnancies complicated by diabetes. Gynecol Obstet Invest 1996; 41 (1): 10-4. 